\title{
The effect of TRX exercises on serum levels of IGF-1 and cortisol and some health-related physical factors in active women
}

\author{
Soleyman Ansari Kolachahi', Alireza Elmieh ${ }^{2}$, Mona Talebi $^{3}$ \\ ${ }^{1}$ PhD of Sport Physiology, Department of Physical Education and Sport Sciences, Faculty of Humanities, Rasht \\ Branch, Islamic Azad University, Rasht, Iran \\ ${ }^{2}$ Assistant Professor, Department of Physical Education and Sport Sciences, Faculty of Humanities, Rasht Branch, \\ Islamic Azad University, Rasht, Iran \\ ${ }^{3}$ MSc of Physical Education, Department of Physical Education and Sport Sciences, Faculty of Humanities, Rasht \\ Branch, Islamic Azad University, Rasht, Iran
}

\begin{abstract}
Background: The most important anabolic and catabolic hormones which levels are altered by resistance training are IGF-1 and cortisol, respectively. The purpose of the present study was to investigate the effect of total body resistance training (TRX) on serum levels of IGF-1, cortisol and some health-related physical factors in active women.

Materials and methods: In this study, 20 active women (mean age $27.05 \pm 3.11$ ) were randomly divided into experimental $(\mathrm{n}=10)$ and control $(\mathrm{n}=10)$ groups. The experimental group program consisted of TRX training for 6 weeks, 3 sessions per week for 50-60 minutes under the supervision of a TRX trainer. The intensity of the exercises for the first two weeks, using the Borg scale was in the range of 4-5, in the second and the third two weeks, based on the increase in load in the range of 5-6 and 6-7, respectively. Serum levels of IGF-1, cortisol, body fat percentage, upper and lower body strength and endurance were measured before and after exercise.

Results: Six weeks of TRX training increased cortisol and IGF-1 levels in active women, although this increase was not statistically significant $(\mathrm{p}>0.05)$. But the results showed that these exercises can significantly decrease body fat percentage and increase the strength and endurance of the upper and lower muscles of active women.

Conclusion: According to the findings of the present study, it seems that performing the TRX training can significantly improve body fat percentage, strength and muscle endurance in active women and could utilize as an alternative resistance training model to improve fitness factors.
\end{abstract}

Keywords: TRX, Insulin-like growth hormone-1, Cortisol, Strength, Muscle endurance, Body fat percentage.

Cited as: Ansari Kolachahi S, Elmieh A, Talebi M. The Effect of TRX Exercises on Serum Levels of IGF-1 and Cortisol and some health-related physical factors in Active Women. Medical Science Journal of Islamic Azad University, Tehran Medical Branch 2020; 30(4): 432-442.

Correspondence to: Alireza Elmieh

Tel: 00989111359121

E-mail: elmieh@iaurasht.ac.ir

ORCID ID: 0000-0002-6266-0018

Received: 20 May 2019; Accepted: 2 Sep 2020 
مجله علوم يزشكى دانشگاه آزاد اسلامى

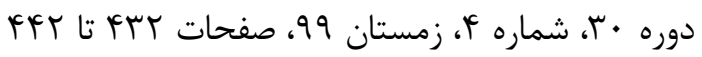

Original

Article

\title{
بررسى اثر تمرينات TRX بر سطوح سر مى هورمونهاى IGF-1 و كورتيزول و برخى عوامل تندرستى آمادگى جسمانى در زنان فعال
}

\author{
سليمان انصارى كلاجاهى'؛ عليرضا علميه؟، مونا طالبى
}

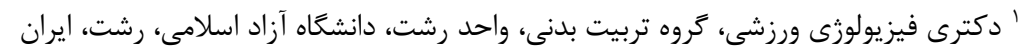

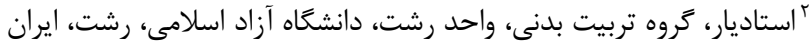

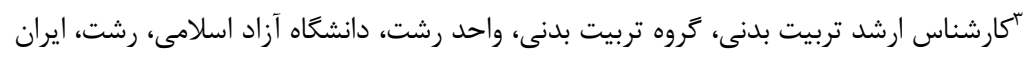
جكيده

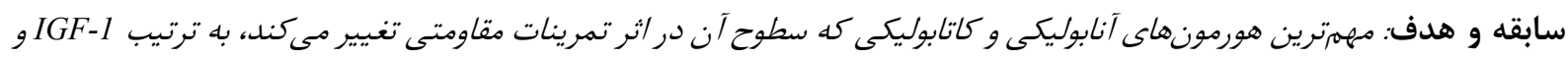

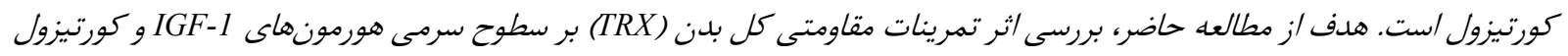

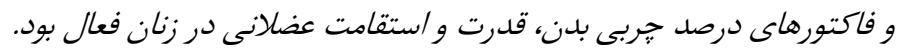

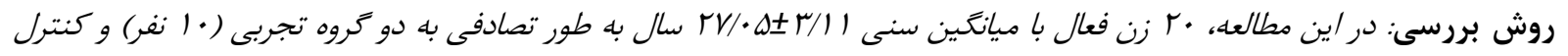

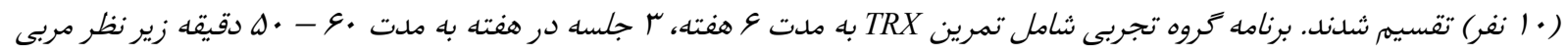

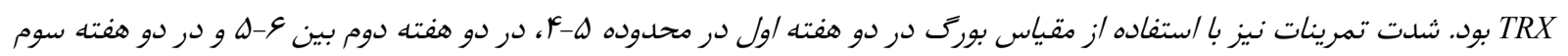

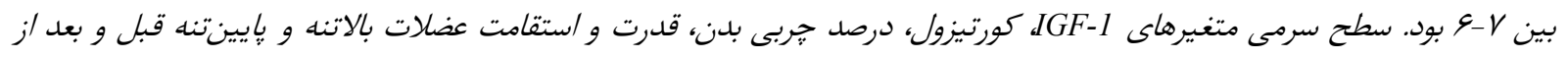
تمرينات اندازمكيرى شدند.

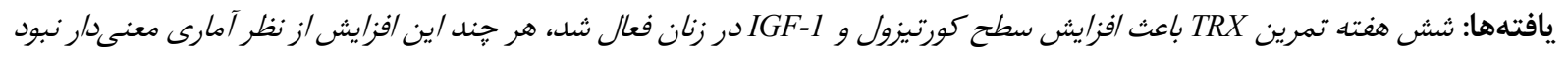

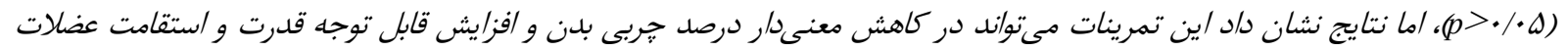

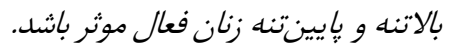

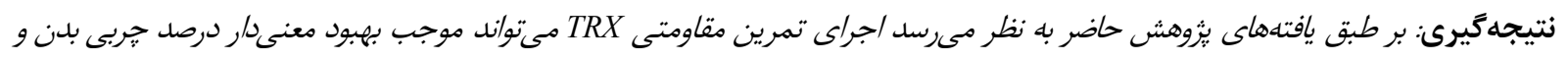

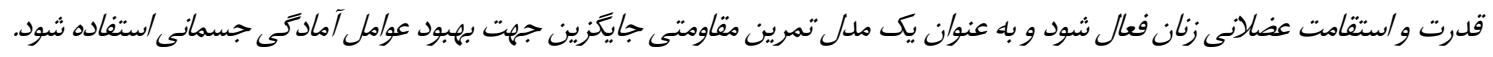

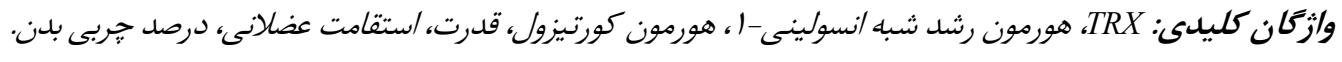

بين محور مركزى طناب رخ مىدهد و از دو دستخيره و بدنه

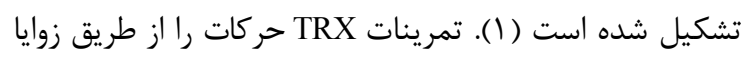

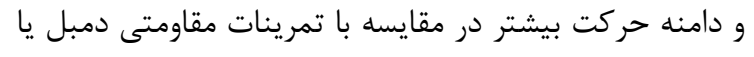

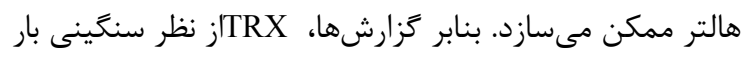

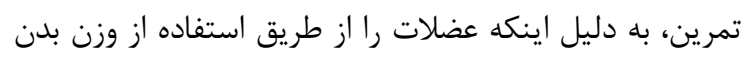

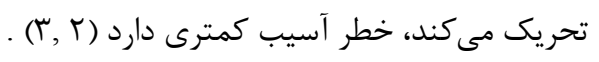

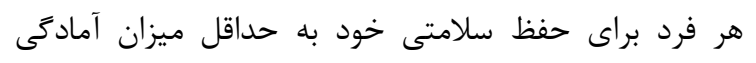
جسمانى جهت انجام تكاليف روزمره و اوقات فراغت نياز داردي

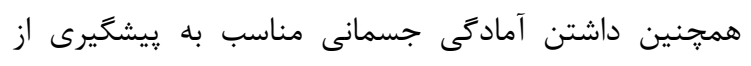

مقدمه

Total Resistance Exercises; ) تمرينات مقاومتى كل بدن تكنيك تمرينى جديدى است كه با استفاده از طناب (TRX يا بند انجام مىشود و در آن انقباض عضلات از طريق فاصله تديدي

آدرس نويسنده مسئول: رشت، دانشخاه آزاد اسلامى، واحد رشـت، كـروه تربيـت بــنى، عليرضـا علميـهـ

(email: elmieh@iaurasht.ac.ir) ORCID ID: 0000-0002-6266-0018 تاريخ دريافت مقاله: • ت •

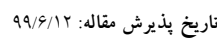




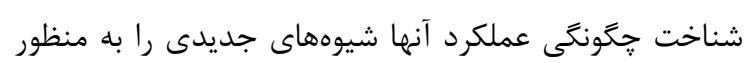

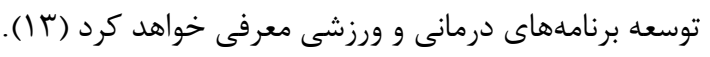

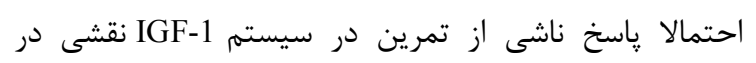
تحريك سازكارىهاى تمرينى ايفا مى كند، كه به اله معنى دانش

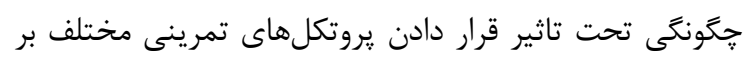

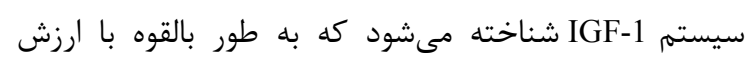

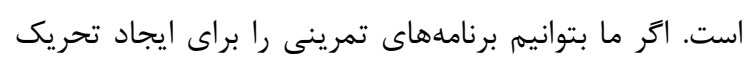

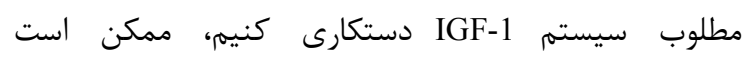

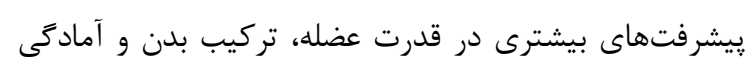

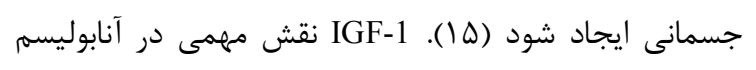

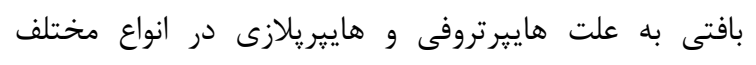

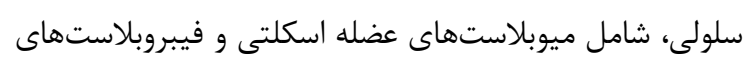

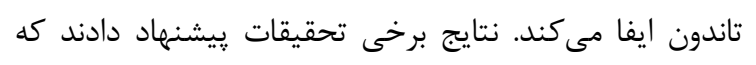

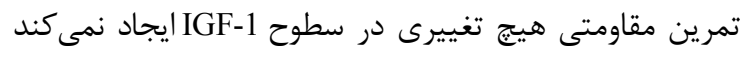
(f)

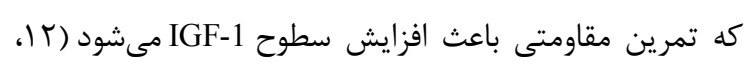

(IV-r)

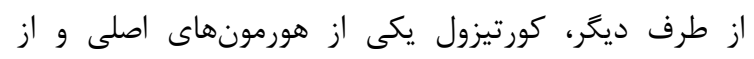

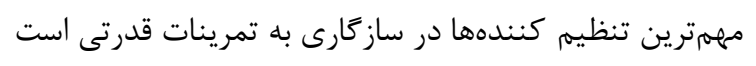

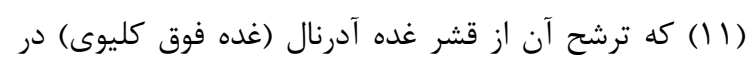

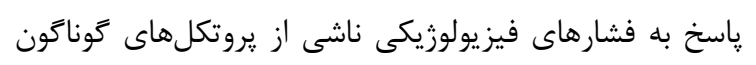

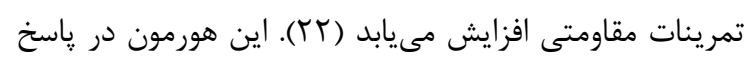

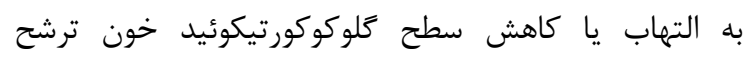

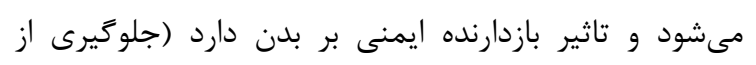

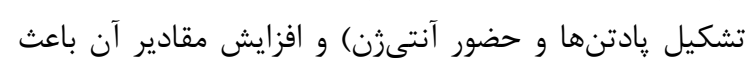

كاهش توان سيستم دفاعى بدن مىشود (T) بادن).

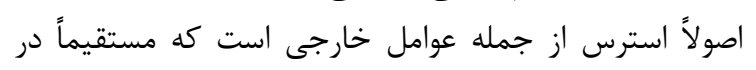

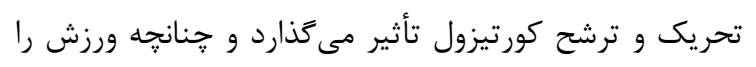
به عنوان يك استرس ييش بينى شده محسوب كنيم، در انواع

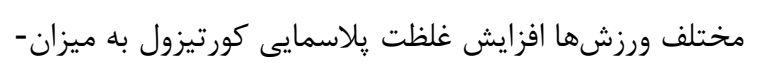

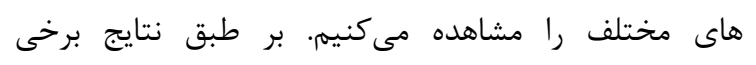

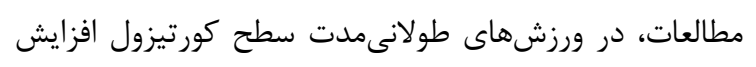

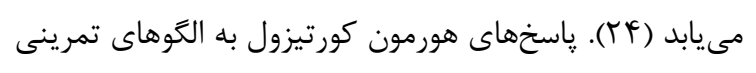

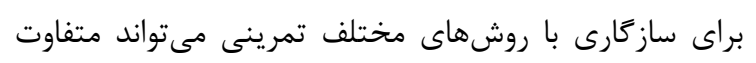

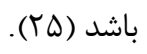

نتايج برخى مطالعات يِيشنهاد دادند كه تمرين مقاومتى باعث

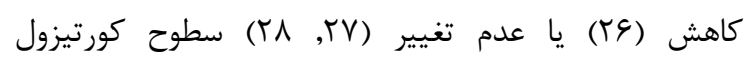
مىشود؛ از سوى ديخر، برخى محققان دريافتند كه تمرين

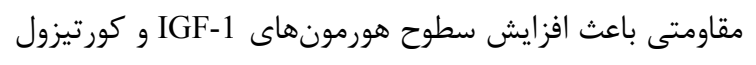
مىشود (^, 9ץ). اما تاكنون مطالعاتى در مورد تاثير تمرينات
بيمارىهاى قلبى، فشار خون، ديابت، يوكى استخوان و داشتن

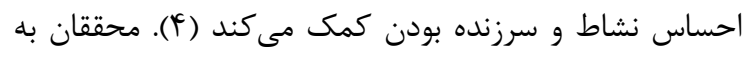

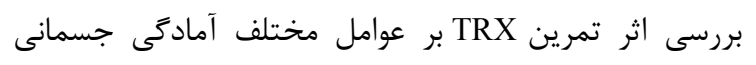

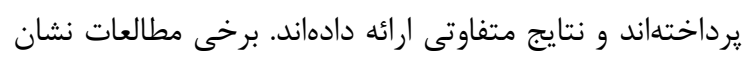

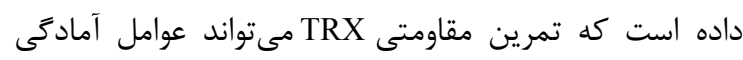

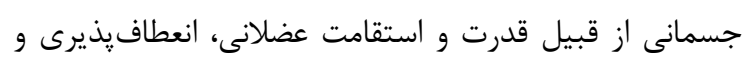

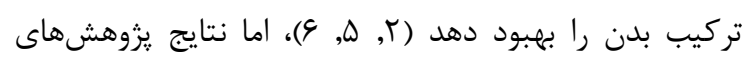

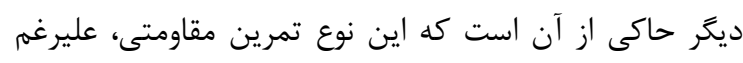

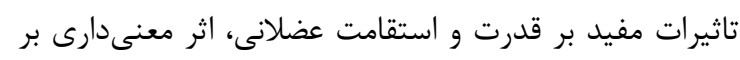

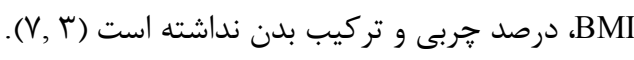

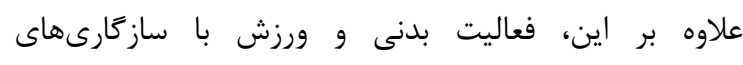

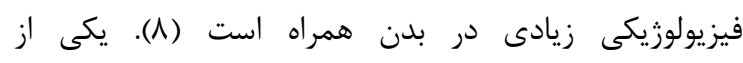

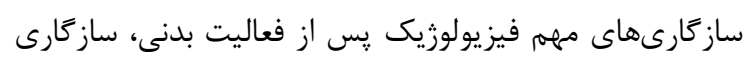

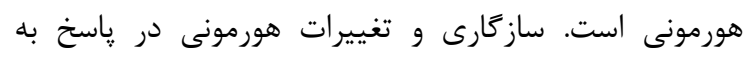

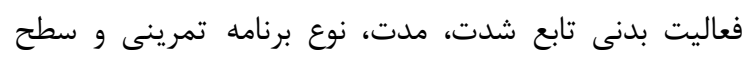

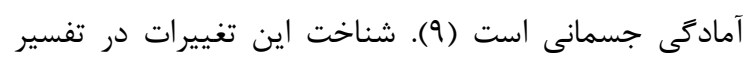
مكانيسمهاى فيزيولوزيكى بدن موثر است (^). تاثيرات دستخاه

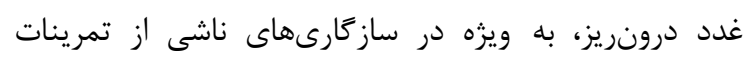

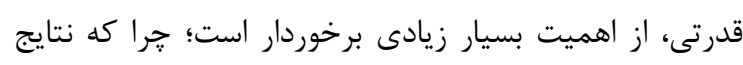

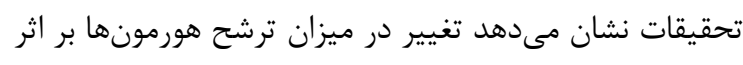

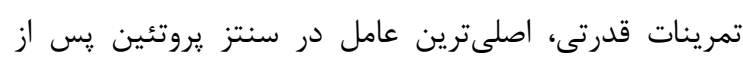

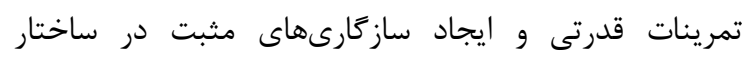
عضلات اسكلتى است (· (1).

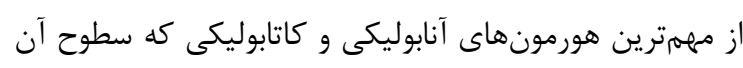

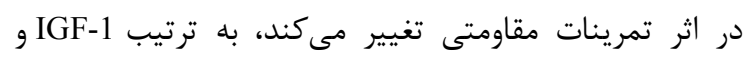

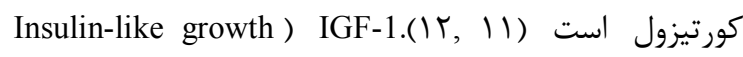
شاخصى زيستى است كه جنبdهاى سودمند فعاليت (factor 1

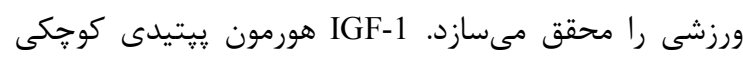

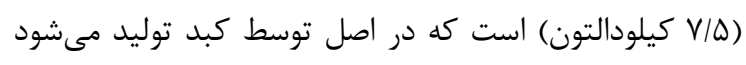

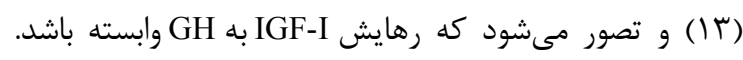

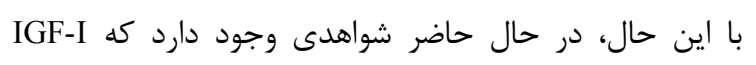

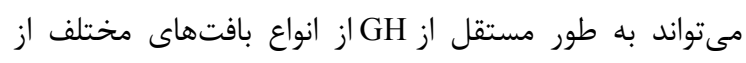

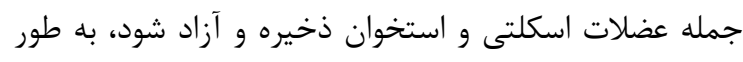

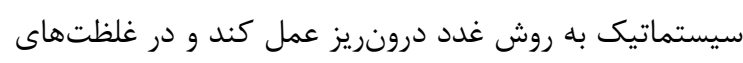

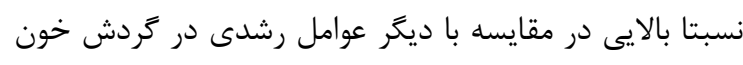

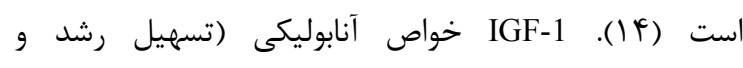

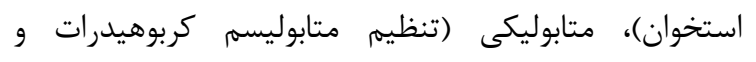

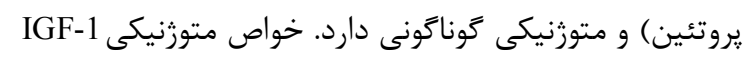

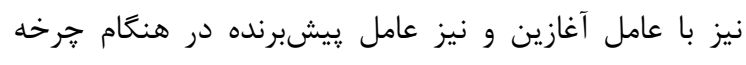
رشد سلولى ارتباط دارد. به همين دليل شناسايى اين عوامل و وانيل 
يزشك معتمد و متخصص علوم ورزشى (محقق) انجام گرفت. يثوهشگران به منظور تعيين ميزان فعاليت بدنى هر فرد و

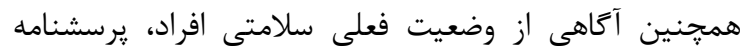
سنجش ميزان فعاليت بدنى و :برسشنامه سابقه يزشكى را بين افراد توزيع كردند. يس از تكميل يرسشنامهها، افراد تحت

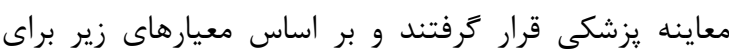
ورود به مطالعه انتخاب شدند. معيارهاى ورود به مطالعه شامل فعال بودن (داشتن حداقل • ب دقيقه فعاليت بدنى متوسط در روز براى سه روز در هفته طى حداقل $\&$ ماه قبل)، عدم ابتلا

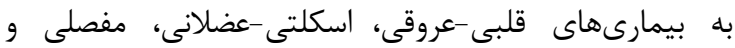

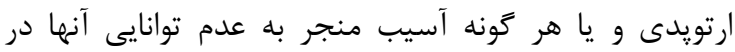

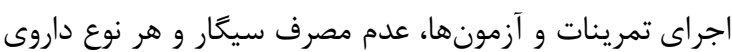
منجر به تغيير سطوح IGF-1 و كورتيزول بود. معيارهاى خروج افراد از مطالعه شامل داشتن بيش از دو جلسه غيبت در زمان اجراى يروتكل تمرينى، مبتلا شدن به بيمارىهاى ذكر

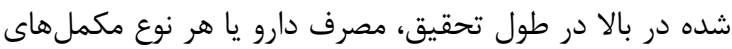

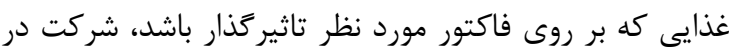

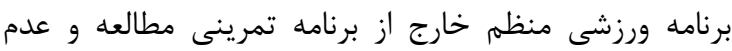
شر كت در انجام آزمايشات بود. در ادامه، شركتكنندگًان به طور تصادفى در دو گروه تجربى
بر روى سطوح هورمون كورتيزول و IGF-1 انجام نشده

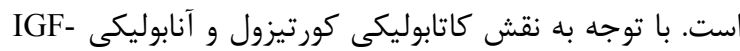

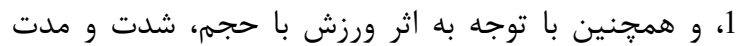
كوناگون بر روى ترشح اين هورمونها، هدف از تحقيق حاضر،

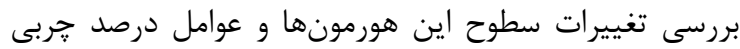
بدن، قدرت و استقامت عضلانى در اثر تمرينات TRX بود.

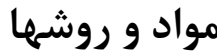

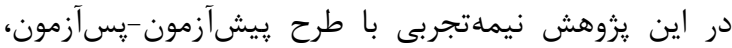

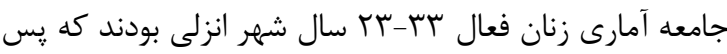

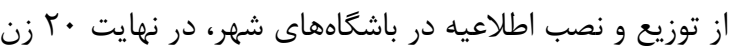
كه داوطلبانه براى همكارى در اجراى تحقيق، اعلام آمادگى

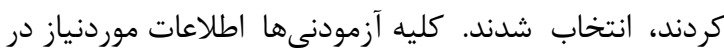
خصوص يروهش را به صورت مكتوب دريافت كردند و يس از مطالعه از آزمودنى ها خواسته شد تا در صورت تمايل به شركت بـ بـ در يثروهش، رضايتنامه كتبى امضا كنند. در راستاى رعايت

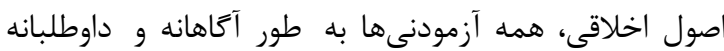
موافقت خود را براى شركت در طرح اعلام كردند و مجاز به به إنه ترك برنامه در هر مرحلهاى شدند. تمام مراحل تحقيق زير نظر

جدول ا. مراحل انجام تمرينات مقاومتى TRX

\begin{tabular}{|c|c|c|}
\hline 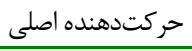 & نحوه اجرا & مراحل تمرين \\
\hline سينه اى بزرى & آزمودنى يشت به نقطه اتصال مىايستد. دستخيرههاى TRX را كرفته و بدن را به جلو متمايل مسىكنـد. بـه تسـمههـا & يرس سينه \\
\hline 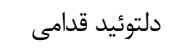 & 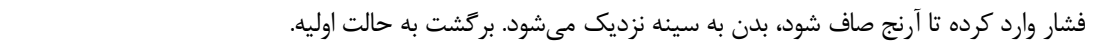 & \\
\hline \multicolumn{3}{|l|}{ سه سر بازو } \\
\hline ذوزنقه اى & آزمودنى رو به سمت نقطه اتصال مىايستد. دستخيرههاى TRX با حركت يرونيشن رو به خارج گرفته و با ايجـاد يــ & قايقى \\
\hline 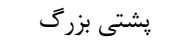 & زاويه مناسب به عقب متمايل شده و بدن را در يك خط راست حفظ مى كند. دسـتهـا بايسـد راسـت در جلـوى بــن & \\
\hline \multirow[t]{2}{*}{ دلتوئيد } & باشند آرنج ها خم شده و با نيروى توليد عضلات دركير بدن به سمت بالا كشيده مىشود؛ تا جايى كه دسـهــا كنــار & \\
\hline & بالا تنه به سينه برسند. برگشت به حالت اول. & \\
\hline جهار سر & آزمودنى رو به سمت نقطه اتصال مىايستد. با تريب دستان در حالت طبيعى، زانو خم مىشود تا جايى كـهـ مـوازى بـا & 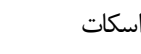 \\
\hline \multicolumn{3}{|c|}{ سطح زمين شود. زانو از انگشتان پا جلو نزند (استفاده از دستان براى حفظ تعادل)؛ بركشت به حالت اول. } \\
\hline \multicolumn{3}{|l|}{ سرينى } \\
\hline \multirow[t]{2}{*}{ سه سر بازو } & آزمودنى يشت به سمت نقطه اتصال مىايستد. هر دو دست گيره توسط دستها گرفته مىشود. بدن بايد در يك خـط & 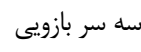 \\
\hline & صاف و آرنج ها در راستاى شانه باشند. آرنج ها را تا • 9 درجه خم شده و سيس به موقعيت شروع بركشته مىشود. & \\
\hline \multirow[t]{3}{*}{ همسترينگ } & آزمودنى به حالت طاقباز دراز كشيده، ياشنهها را داخل تسمه و كف پا بر روى تسمه قرار داده مىشود؛ زاويه بـين زانـو & يل \\
\hline & و بدن بايد •و درجه باشد. دستها كنار بدن، باسن از زمين جدا شده و بالا برده مىشود. به وضعيت شروع برَشـته و & \\
\hline & حركت تكرار مىشود. - ( & \\
\hline \multirow[t]{2}{*}{ دو سر بازو } & آزمودنى رو به نقطه اتصال مىايستد. آرنج ها صاف است. هر دو دستخيره با كف دستها كرفته مىشود؛ به بدن شـيب & 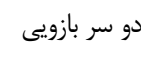 \\
\hline & داده آرنج ها خم و بدن به سمت بالا كشيده مىشود. بركشت به حالت اول. & \\
\hline \multirow[t]{3}{*}{ 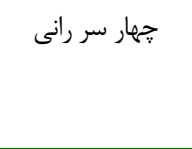 } & 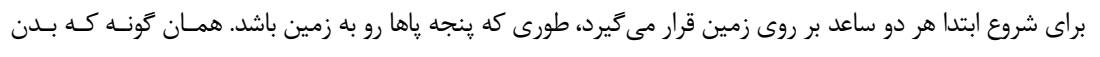 & خم كردن زانو \\
\hline & در اين وضعيت (شبيه شناى سوئدى) قرار دارد؛ زانوها خم شده و پاها به بدن نزديك مى شود. (وضعيت كامـل شـبيه & \\
\hline & حركت قورباغه است). سيس به وضعيت شروع بر مى گردد. & \\
\hline
\end{tabular}


سطح قدامى ران) با استفاده از دستخاه كاليير سيهان (سـاخت

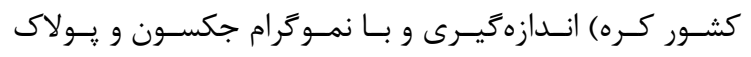

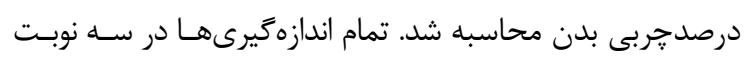

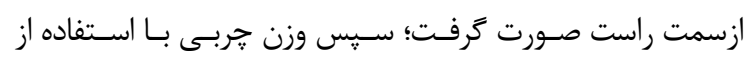
فرمولهاى زير محاسبه شد (Tها).

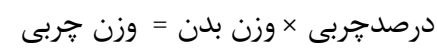

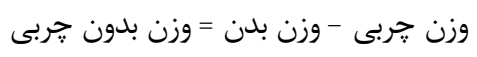
(روش جكسون /يولاك: $-\cdot / 1494 \cdot \cdots \cdot$

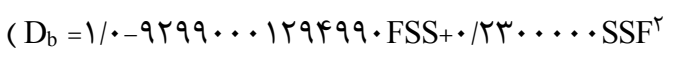

جمع جينهاى يوستى سه سر بازو، فوق خاصره و ران=

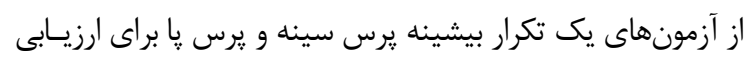

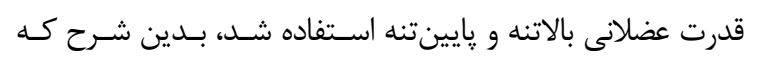

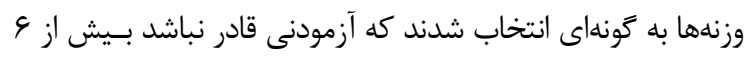

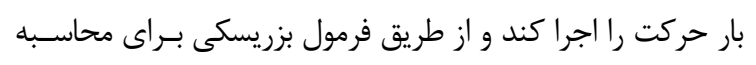

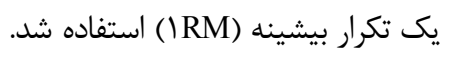

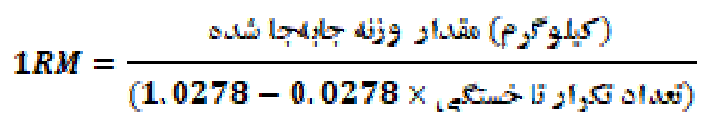

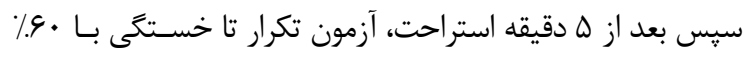

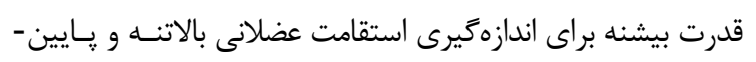
تنه توسط شركت قنند

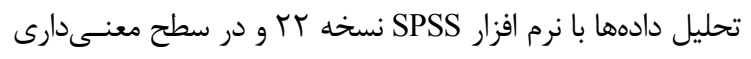

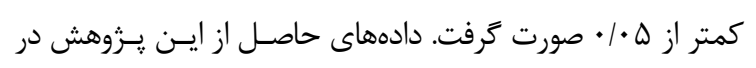

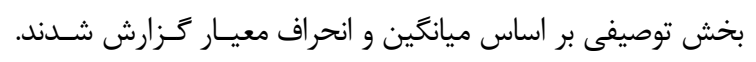

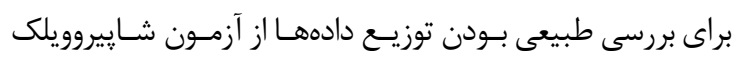

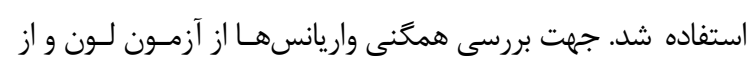

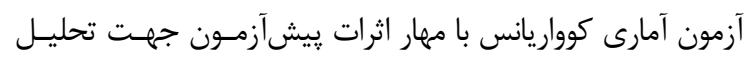
دادههاى يزوهش در گروههاى مورد مطالعه استفاده شد.

ملاحظات اخلاقى

IR.IAU.RASHT.REC.1397.036 اين تحقيق داراى كد اخـات اخلاقي و كد كارآزمايى بالينى داري كد اخلى إق است. IRCT20180503039517N2

\section{يافتهها}

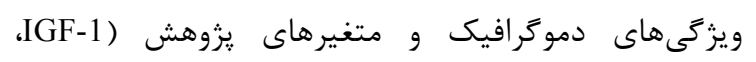

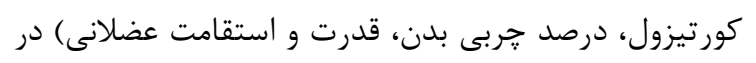

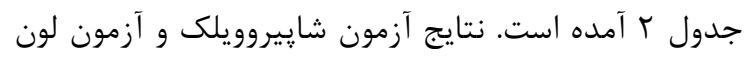

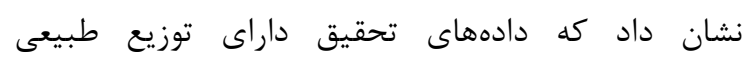

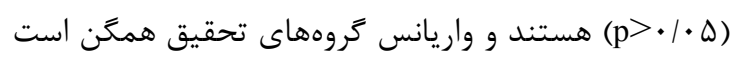

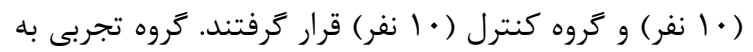

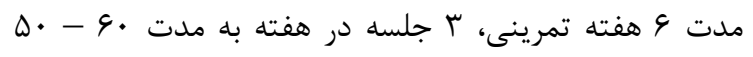

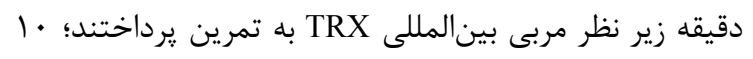

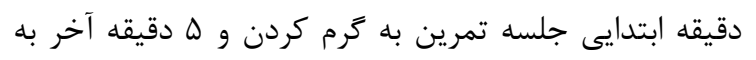
حركات كششى جهت سرد كردن اختصاص داده شد. تمرينات

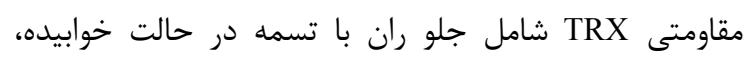

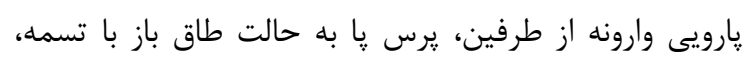

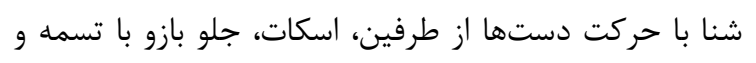

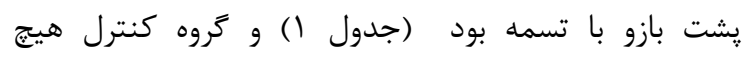

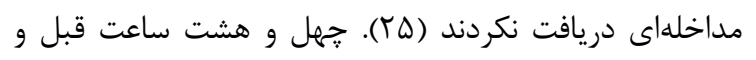

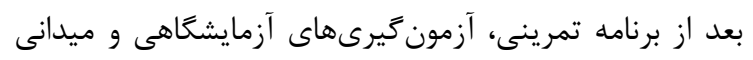
صورت ترفت.

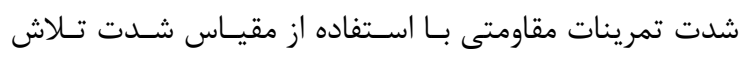

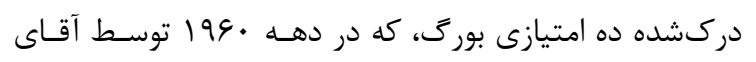

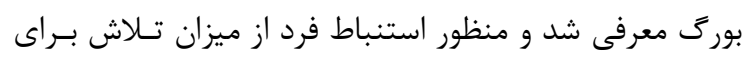

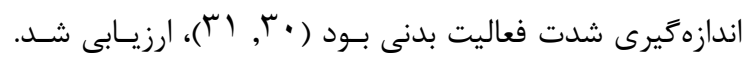

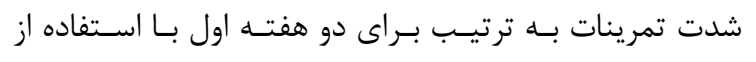

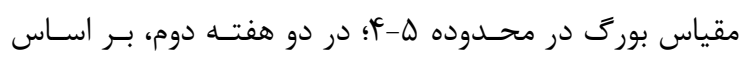

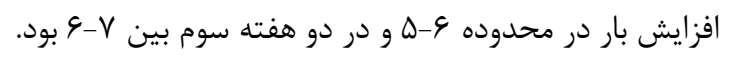

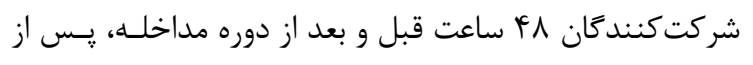

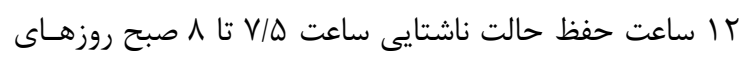

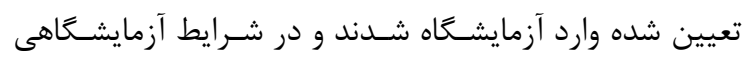

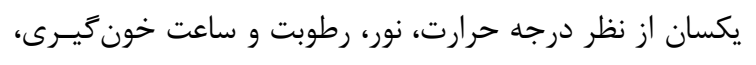

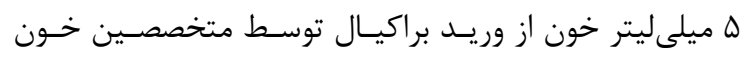

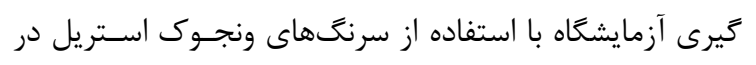

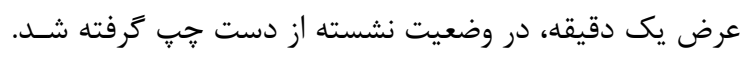

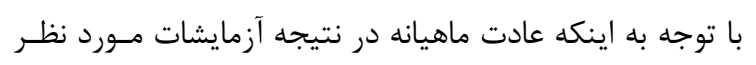

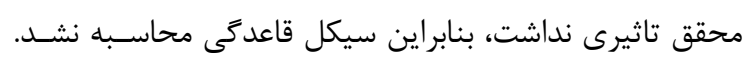

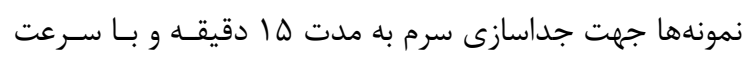

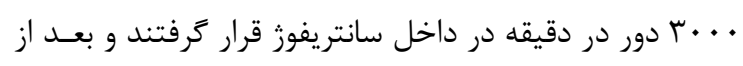

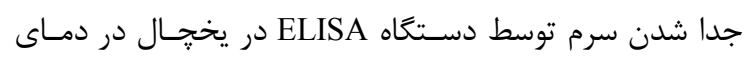

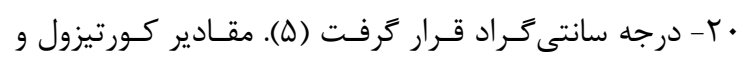

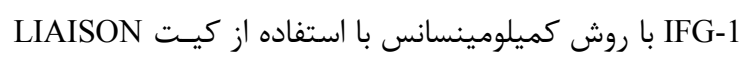

$$
\text { ساخت كشور اسيانيا اندازمخيرى شد. }
$$

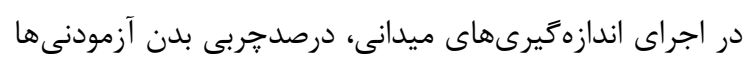

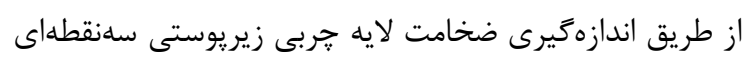
در نواحى سهسر بازويى (نقطه ميانى بين زايده آخرمى و زايده لـانه

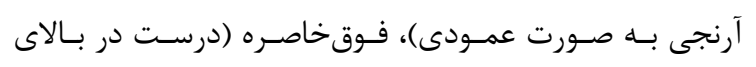

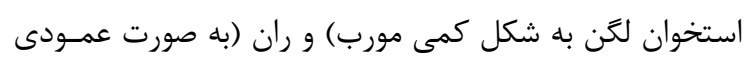

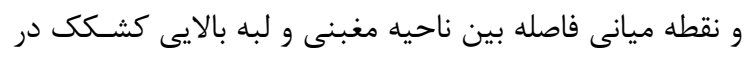


اما در متغيرهاى درصد جربى زيرجلدى، قدرت و استقامت

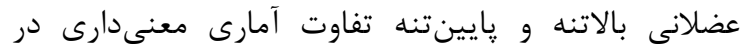

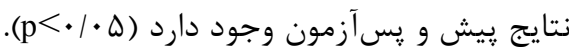

بحث تمرينات TRX از جمله تمرينات مقاومتى جديدى است كه امروزه در دنياى ورزش و تناسب اندام جايگاه ويزهاى يافته و محبوبيت زيادى ريدا كرده است. طبق تحقيقات، اخيرا نشان ورون داده شده است كه تمرينات TRX روى انرزى مصرفى و متغيرهاى متابوليكى و تغييرات سطوح برخى هورمونها تاثيرات بسزايى دارد. اينكه فعاليتهاى بدنى مختئي مختلف بر ميزان ترشح هورمون كورتيزول و IGF-1 مى تواند متفاوت باشد، خود كمال اهميت را داراست. هدف از اين مطالعه، بررسى اثر تمرين TRX بر مقادير سطح سرمى هورمونهاى كورتيزول و IGF-1 عضلات بالاتنه و وايينتنه زنان فعال بود. در اين تحقيق مشاهده شد كه به دنبال شش هفته تمرين

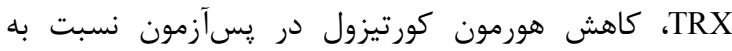
ييشآزمون در گروه تجربى بلهوجود آمده است، اما اين كاهش از نظر آمارى معنى دار نبود. همجنين تفاوت معنى دارى بين دو زروه تجربى و كنترل مشاهده نشد. معمولا تمرينات مقاومتى يك محرك قوى براى افزايش ماد غ غلظت هورمونهاى در گردش خون نظير هورمون رشد، تستوسترون

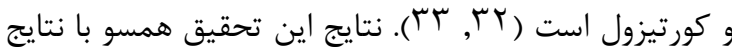
تحقيق صورتى و همكارانش (r| • r) و رضايى و همكارانش (| (|) بود. صورتى و همكارانش در تحقيق خود با عنوان اثر
(ه> • (p). بنابراين با توجه به توزيع نرمال و تجانس

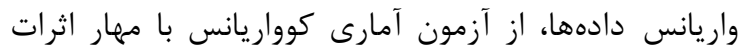

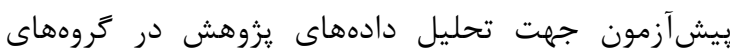

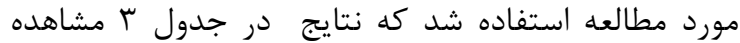
مى شود. نتايج آزمون كوواريانس نشان داد كه در متغيرهاى كورتيزول و IGF-1 بين گروههاى مورد مطالعه، از لحاظ

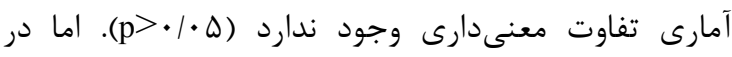
مورد ساير متغيرهاى موجود در اين مطالعه، در بين گروهها

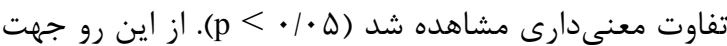
مشخص شدن نقطه تفاوت بين گروههاى مورد مطالعه از آزمون تعقيبى بونفرونى و همجنين براى مشخص كردن

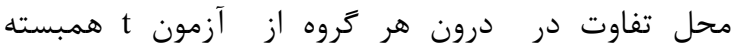
استفاده شد كه در جدول \& أ ارايه شده است. نتايج آزمون تعقيبى بونفرونى نشان داد كهد ده در در متغير كورتيزول و IGF-1 در بين گروههاى تمرين و كنترل تفاوت

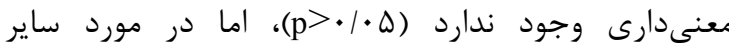
متغيرهاى مورد بررسى شامل درصد جربى زيرجلدى، قدرت يايينتنه و بالاتنه، و استقامت عضلانى يايينتنه ور بالاتنه بين گروههاى تجربى و كنترل اختلاف معنى بارى مشاهده

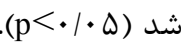
همجنين از آزمون t t همبسته براى بررسى تفاوت درون

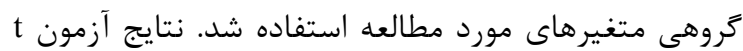

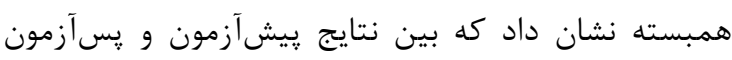
كروهها در متغير كورتيزول و IGF-1 در بين گروههاى

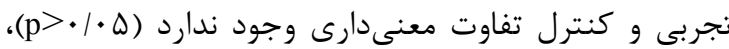

جدول r. ويزگى هاى دموگرافيك و متغيرهاى يزوهش زنان فعال در دو گروه تجربى و كنترل

\begin{tabular}{|c|c|c|c|c|}
\hline \multicolumn{2}{|c|}{ كروه كنترل } & \multicolumn{2}{|c|}{ عروه تجربى } & \multirow[t]{2}{*}{ متغير } \\
\hline يس آزمون & مِيش آزمون & يس آزمون & لِيش آزمون & \\
\hline- & $r q / 9 \cdot \pm r / 9 V$ & - & $r V / V \cdot \pm r / 19 *$ & سن (سال) \\
\hline- & $1 / \varepsilon r \pm \cdot / \cdot \Delta$ & - & $1 / \varepsilon \mu \pm \cdot 1 \cdot \Delta$ & قد (سانتىمتر) \\
\hline$\Delta \Lambda / \mu F \pm F / \Lambda \Lambda$ & $\Delta V / \cdot \cdot \pm F / \Delta T$ & $\Delta V / / 9 \pm \varepsilon / \Delta r$ & $\Delta 9 / 1 \cdot \pm \varepsilon / 9 \vee$ & وزن (كيلوكرم) \\
\hline$r T / I V \pm I / 9 \Lambda$ & $r \mid / 99 \pm r / \cdot r$ & $\lceil I / r \wedge \pm 1 / V q$ & $r r / \cdot 9 \pm 1 / 9 \varphi$ & (كيلوَرم بر مترمربع) BMI \\
\hline $1 V / 9 \cdot \pm r / 19$ & $r \cdot / \cdot \cdot \pm r / \cdot V$ & $\mid N / \Delta S \pm F / T$ & $r \cdot / 19 \pm r / \Delta r$ & 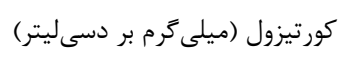 \\
\hline $\mid V \Delta / 9 \vee \pm \Delta \cdot / \cdot F$ & $\mid \varepsilon q / V V \pm r \Delta / q 1$ & $r I V / V V \pm F r / T F$ & $t \mid N / I \cdot \pm D \cdot / 4 t$ & IGF-1 (ميلى \\
\hline$r \Delta / \Lambda \Lambda \pm r / \Delta V$ & $r \Delta / \varsigma \wedge \pm r / \Lambda)$ & $r \cdot / l \cdot \pm r / r$ & $r / / \wedge \Delta \pm r / 9 r$ & درصد جربى زيرجلدى \\
\hline$q 4 / 4 \cdot \pm 19 / 9 \Lambda$ & $q 4 / \Delta \cdot \pm r \cdot \pi r$ & $9 \cdot 10 \cdot \pm 19 / \wedge r$ & $\vee q / \Lambda \cdot \pm / V / f q$ & قدرت پايين تنه \\
\hline$r V / V \cdot \pm r / \Delta T$ & $r V / \Lambda \cdot \pm F / \Delta F$ & $r \varepsilon / r \Delta \pm r / q$. & $r \Psi / T \cdot \pm r / l Q$ & قدرت بالاتنه \\
\hline $\mid 1 / 1 \cdot \pm 1 / 99$ & $\mid V / q \pm 1 / T V$ & $r I / \Lambda \cdot \pm I / \Delta F$ & $\mid V / G \cdot \pm I / \Delta V$ & استقامت بالاتنه (تكرار) \\
\hline$r \Delta / \Lambda \cdot \pm 1 / \mathcal{E V}$ & $r \Delta / V \cdot \pm 1 / \uparrow q$ & $r \Lambda / G \cdot \pm 1 / \Delta \cdot$ & $r \Delta / r \cdot \pm 1 / v \cdot$ & استقامت پِايين تنه (تكرار) \\
\hline
\end{tabular}


جدول r. نتايج آزمون كوواريانس در متغيرهاى مورد مطالعه

\begin{tabular}{|c|c|c|c|c|c|c|c|c|}
\hline توان آزمون & مقدار اثر & معنادارى & $\mathrm{F}$ & مجذانگين & آزادى درج & مجذورات & منابع تغيير & متغيرها \\
\hline .1 .99 & $.1 \cdot 11$ & $.19 \vee \Delta$ & $\cdot / 11$ & r/TF & 1 & r/TF & ييشآزمون & كورتيزول (ميلى \\
\hline$\cdot / \cdot v \Delta$ & $.1 \cdot 1 \mathrm{~F}$ & .1949 & $\cdot / T F$ & F/FT & 1 & $F / F$ & تروه & بر دسى ليتر) \\
\hline- & - & - & - & $\mid \Lambda / r$ & IV & r & خطا & \\
\hline $1 / \cdots$ & • & $\cdot 1 \cdot \cdot v$ & $q / r \Delta$ & $1711 \cdot / 99$ & 1 & $1 r \wedge 1 \cdot 199$ & يِيشآزمون & IGF-1 (ميلى گرم بر \\
\hline$\cdot \mid \cdot \vee 1$ &.$/ \cdot 14$ & $\cdot 19 \Delta 9$ & $\cdot / r \cdot 4$ & $r \cdot \Lambda / V r$ & 1 & $r \cdot \Lambda / V r$ & تروه & ميلى ليتر ) \\
\hline- & - & - & - & $\mid f 99 / 14$ & IV & $r \Delta F \wedge \Delta / F$. & خطا & \\
\hline $1 / \cdots$ & . /9DT & $\cdot 1 \cdot \cdot 1$ & ( & rזוצזו & 1 & سז/צrו & ״يشآزمون & درصد جربى بدن \\
\hline $1 / \cdots$ & $\cdot \mid 9 \wedge 1$ & $* 1 \cdot \cdot 1$ & r & IF/AT & 1 & IF/AT & كروه & \\
\hline- & - & - & - & $\cdot / \boldsymbol{f}$ & IV & $9 / 94$ & خطا & \\
\hline $1 / \cdots$ &.$/ 9 T \Delta$ & $\cdot / \cdot 1$ & $T \cdot N / T r$ & $9 \Delta Q \wedge / F \Delta$ & 1 & $9 \Delta 9 \Lambda / F \Delta$ & ييشآزمون & قدرت پايين تنه \\
\hline.$/ 909$ & . IFVT & $* 1 \cdot .1$ & $\mid 0 / 11$ & $4 \wedge 1 / .9$ & 1 & $\mid \wedge \lambda 1 / .9$ & كروه & \\
\hline- & - & - & - & $r M / 9 V$ & IV & $\Delta H \Lambda / F F$ & خطا & \\
\hline $1 / \cdots$ & - IAVG &. $\mid \cdot 1$ & $1 T \cdot 19$. & $r \Delta \cdot / \Lambda \varphi$ & 1 & $r \Delta \cdot / \Lambda \varphi$ & ييشآزمون & قدرت بالاتنه \\
\hline ./VVG & - & $\because .1 .1$ & N/Tr & $T F / T I$ & 1 & $T F / T I$ & كروه & \\
\hline- & - & - & - & $r / 9$. & IV & $F q / F \Delta$ & خطا & \\
\hline $1 / \cdots$ & - IAFD & $\cdot 1 \cdot \cdot 1$ & $9 Y / V 9$ & $r q / r$. & 1 & $r q / r$. & ״يش آزمون & استقامت بالا تنه \\
\hline $1 / \cdots$ &.$/ 918$ & $* 1 \cdot \cdot 1$ & 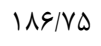 & $\vee 9 / \cdot 9$ & 1 & $\vee 9 / \cdot 9$ & تروه & (تكرار) \\
\hline- & - & - & - & . IFTF & IV & $V / T \cdot$ & خطا & \\
\hline $1 / \cdots$ & $\cdot / V T \Delta$ & $\cdot 1 \cdot \cdot 1$ & $F F / V \Lambda$ & rर/99 & 1 & $r \wedge / 99$ & ييش آزمون & استقامت پِايين تنه \\
\hline $1 / \cdots$ & • & $* 1 \cdot \cdot 1$ & $V r / V \Delta$ & $F V / V F$ & 1 & $F V / V F$ & گروه & (تكرار) \\
\hline- & - & - & - & - lap & IV & $11 / \cdot \cdot \Delta$ & خطا & \\
\hline
\end{tabular}

جدول f. نتايج آزمون تعقيبى بونفرونى بين كروهى و تى همبسته درون گروهى متغيرهاى مورد مطالعه

\begin{tabular}{|c|c|c|c|c|c|c|c|c|}
\hline \multicolumn{3}{|c|}{ نتايج درون گروهى (تى همبسته) } & \multirow[t]{2}{*}{ 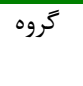 } & \multicolumn{3}{|c|}{ نتايج بينگروهى (بونفرونى) } & \multirow[t]{2}{*}{ كروه } & \multirow[t]{2}{*}{ متغيرها } \\
\hline معنى دارى & درجه آزادى & $\mathrm{T}$ & & معنى دارى & خطاى استاندارد & اختلاف ميانگين & & \\
\hline$\cdot / \pi<q$ & 9 &.$/ 911$ & تمرين & $\cdot 1949$ & $1 / 9 / 4$ &.$/ 941$ & تمرين-كنترل & كورتيزول (mg/dl) \\
\hline$\cdot / T \cdot V$ & 9 & $1 / r \Delta q$ & 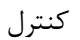 & & & & & \\
\hline •/9人 & 9 & . $1 \cdot k t$ & 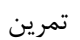 & - $\mid q \Delta \phi$ & $r \cdot / r \Delta$ & $9 / \pi \mu$ & تمرين-كنترل & $(\mathrm{mg} / \mathrm{dl}) \mathrm{IGF}-1$ \\
\hline$\cdot / r \wedge \vee$ & 9 & $\cdot / 9 \cdot 1$ & 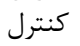 & & & & & \\
\hline$* \cdot 1 \cdot \cdot 1$ & 9 & १/५ १। & تمرين & $* \cdot 1 \cdot \cdot 1$ & •/rfq & $r / 1 \cdot 9$ & تمرين-كنترل & درصد خربى بدن \\
\hline$\cdot / r \wedge \vee$ & 9 &.$/ 9 F t$ & 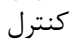 & & & & & \\
\hline$* \cdot \cdot \cdot r$ & 9 & $F / r \Lambda$ & تمرين & $* \cdot 1 \cdot \cdot 1$ & t/RTd & $1 \cdot 1909$ & ت تمرين-كنترل & قدرت پايين تنه \\
\hline$\cdot \mid 091$ & 9 & $\cdot / \Delta \Delta V$ & 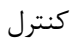 & & & & & \\
\hline$* \cdot 1 \cdot 11$ & 9 & $r / 19$ & تمرين & $* \cdot 1 \cdot 1$. & . INTt & $r / 4 \cdot l$ & تمرين-كنترل & قدرت بالاتنه \\
\hline$\cdot \mid 9 \vee \wedge$ & 9 & . / Frq & كنترل & & & & & \\
\hline$* \cdot 1 \cdot .1$ & 9 & $r \mid / \ldots$ & تمرين & $* \cdot 1 \cdot \cdots 1$ & ./rqน & $r / \ldots$ & تمرين-كنترل & استقامت بالاتنه \\
\hline 每 & 9 & $1 / \cdots$ & كنترل & & & & & \\
\hline$* \cdot 1 \cdot .1$ & 9 & $9 / \wedge \Delta$ & تمرين & $* \cdot 1 \cdot \cdot 1$ & ( & $r / 11$ & تمرين-كنترل & استقامت پايين تنه \\
\hline$\cdot \mid 091$ & 9 & $\cdot / \Delta \Delta V$ & كنترل & & & & & \\
\hline
\end{tabular}

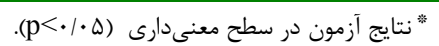

اما از طرف ديكر، نتايج اين تحقيق با نتايج تحقيق دشتى و

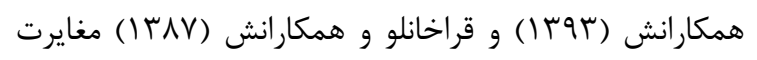

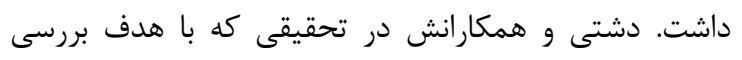

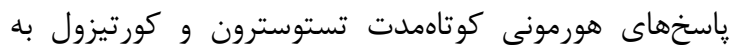

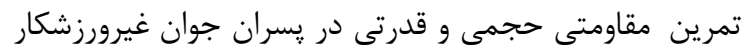

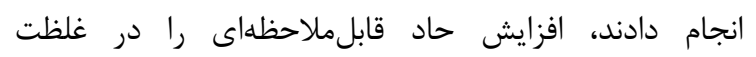

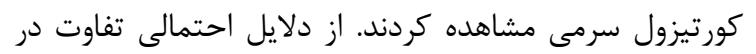

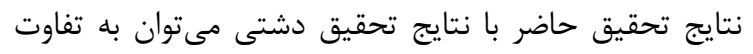

تمرينات مقاومتى و استقامتى بر روى آندروثن، كورتيزول و

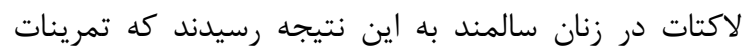

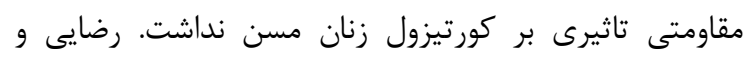

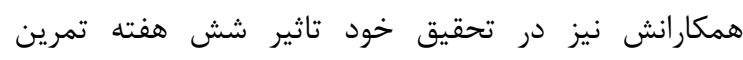

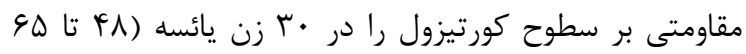

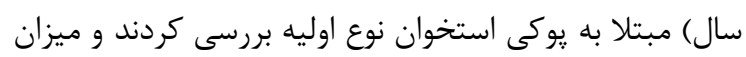

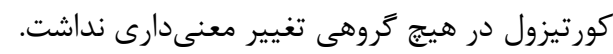


تحقيق گركورى و همكارانش (Y| • (Y)، دادكئون و همكارانش

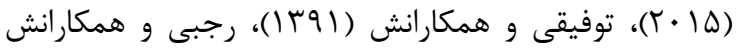

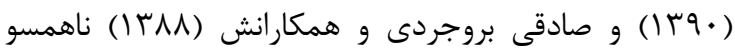
بود. توفيقى و همكارانش، اثر سه نوع تمرين هوازى، مقاومتى

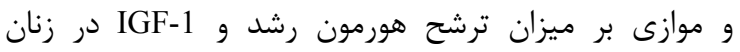

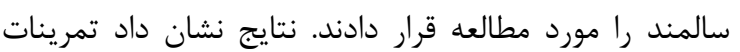
مقاومتى بيشترين افزايش را در ترشح IGF-1 نسبت بهانه تمرينات هوازى و موازى داشته است. از دلايل احتمالى تفاوت

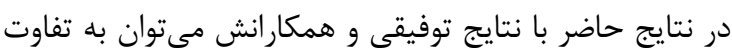

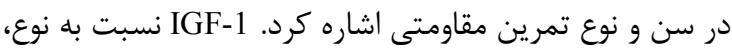

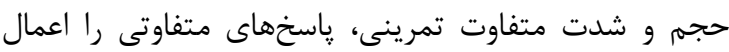

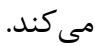
كر كورى و همكارانش در تحقيقى با عنوان تغييرات غلظت فاكتور IGF-1 در اثر ورزش، غلظت اين هورمون را در خون

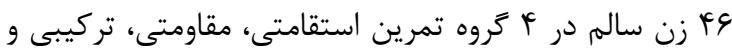
كنترل بررسى كردند و نتايج نشان داد كه بعد از هشت هفته تمرين مقاومتى، غلظت IGF-I بلطور معنى دارى دارى افزايش

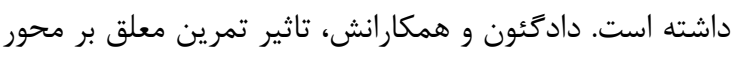

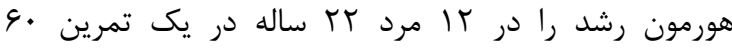

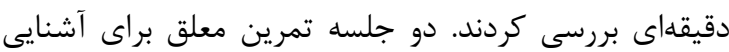

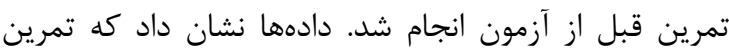

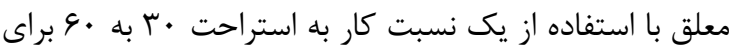

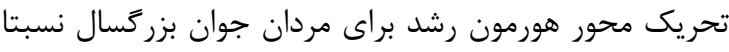

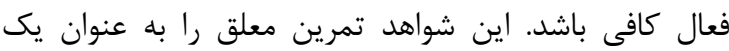

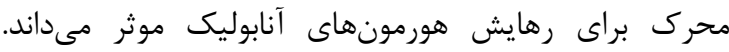
رجبى و همكارانش نيز به بررسى تاثير فعاليت ورزشى

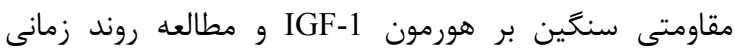
تغييرات اجزاى تركيبى در دانشجويان مرد تمرينكرده و ون

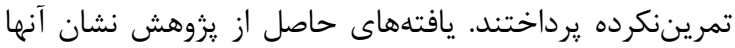

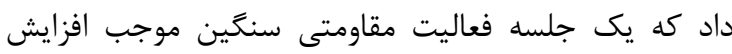
معنى دار IGF-1 شد. همجنين بروجردى و همكارانش، واكنش هورمونهاى GH و IGF-1 نسبت به دو برنامه مقاومتى شديد

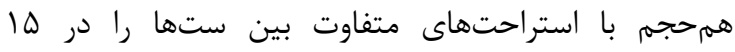
ورزشكار رشته يرورش اندام مورد مطالعه قرار دادند. نتايج نشان داد كه تغييرات هورمون IGF-1 نسبت به قبل از تمرين

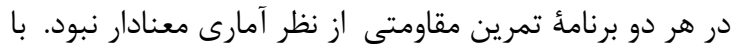

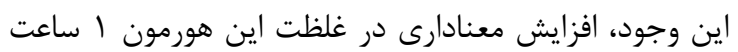

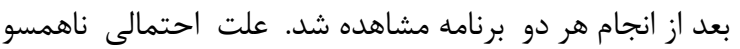

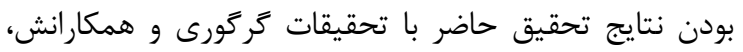
دادكئون و همكارانش، رجبى و همكارانش و بروجردى و و
در جنسيت نمونهها اشاره كرد. نمونههاى تحقيق حاضر رأن دختران فعال تشكيل مىدادند، حال آنكه نمونههاى موجود

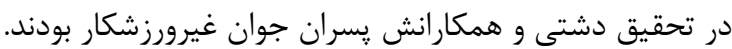
دليل ديكر تفاوت در نتايج مربوط به نوع و مدت زدان زمان تمرين

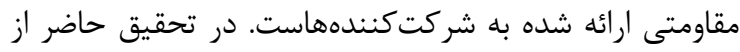

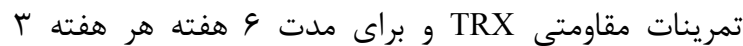
جلسه استفاده شد، اما در تحقيق دشتى و همكارانش، تمرينهاى مقاومتى حجمى و قدرتى در دو جلسه جداكانه به صورت متقاطع براى هر دو كروه تجويز شد.

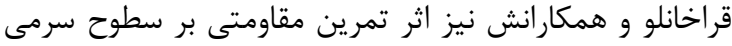

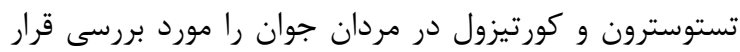

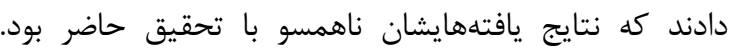
يافتههاى آنها نشان داد تغييرات ايجاد شده با تمرين مقاومتى در تستوسترون و كورتيزول ممكن است در افزايش قدرت و واندان

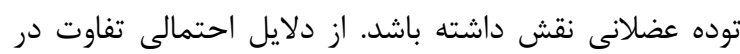

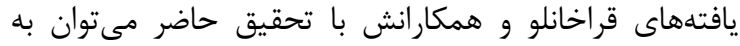

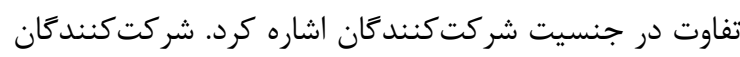

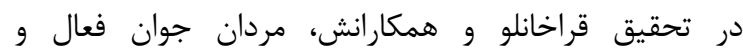
تمريننكرده بودند، حال اينكه افراد تحقيق حاضر راز رنان فران فعال تشكيل مىدادند. از دلايل ديكر اين تفاوت در نتايج، نوع و و

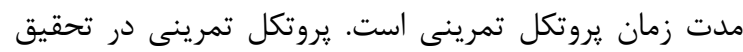

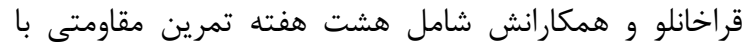

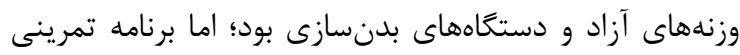
در تحقيق حاضر شامل شش هفته تمرين مقاومتى TRX با بالي طناب و تسمه بود. يكى از اثرات اصلى كورتيزول، كاهش ذخاير يروتئينى در كليه

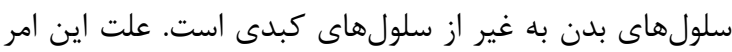
كاهش سنتز و افزايش كاتابوليسم يروتئين موجود در سلول

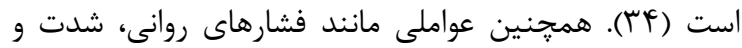
مدت ورزش غلظت كورتيزول سرم را در ورزشكاران تحت تاثير

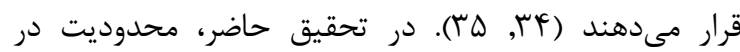
كنترل شرايط روحى و روانى نمونهها، مىتواند يكى از دان دلايل

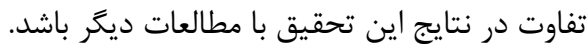

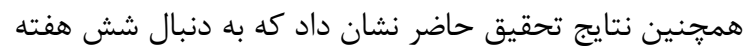

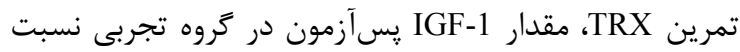

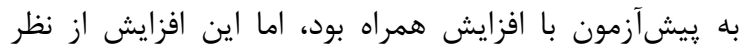

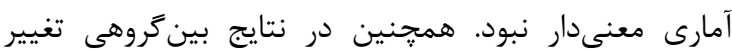
معنى دارى بين دو كروه مشاهده نشد كه اين يافتهها با نتايج تحقيقات عبدى و همكارانش (rq (با)، واكر و همكارانش

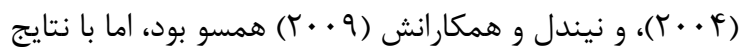


فعال، مىتواند احتمالا به دليل سازگارىهاى موضعى عضله ناشى از افزايش فعاليت آنزيمهاى اكسايشى و كَليكوليتيكى

باشد (V) كه البته در اين تحقيق اندازهخيرى نشده بودند.

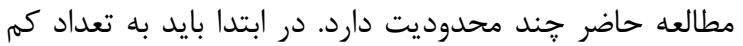
نمونهها اشاره كرد؛ لذا در تعميم يافتههاى تحقيق حاضر بايد

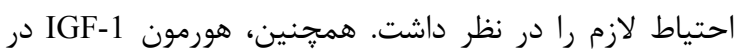
تركيب با حامل خود به نام يروتئين اتصالى عامل رشد شبه

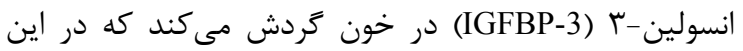
تحقيق اندازهيرى نشده است؛ در نتيجه، براى تعيين اثر دقيق تمرين TRX بر קاسخهاى هورمونى نياز به مطالعات بيشترى است. البته اين تحقيق اولين مطالعهاى بود كه تاثير

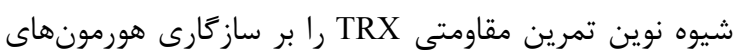
آنابوليك و كاتابوليك در زنان جوان فعال بررسى كرد. در مجموع، نتايج اين مطالعه نشان داد كه تمرينات مقاومتى لئى

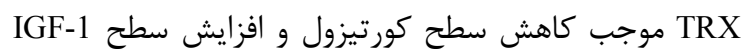
در زنان فعال شد، اما اين تغييرات از نظر آمارى معنى دار نبود.

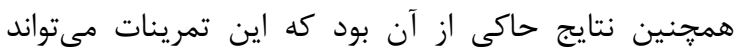

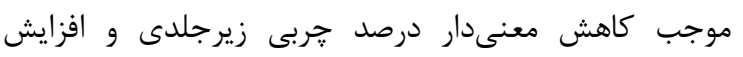
معنىدار قدرت و استقامت عضلانى زنان جوان تمرين كرده شود. براين اساس، زنان جوان فعال مىتوانند از تمرينات TRX

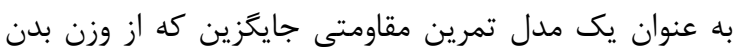

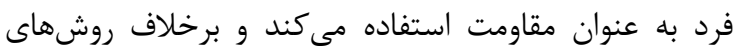

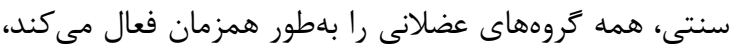
جهت بهبود عوامل آمادگى جسمانى بهره ببرند.

\section{تشكر و قدردانى}

از تمامى شركت كنند

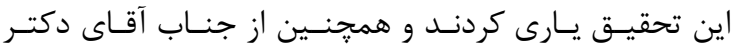
منوجهر احمدى به علت قبول زحمت در يايش نمونهها كمـال تشكر را داريم.
همكارانش را مىتوان به نوع متفاوت تمرينات، شدت، مدت

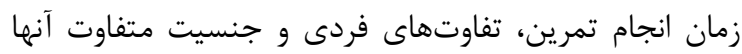
نسبت به تحقيق حاضر دانست. علاوهبراين، يافتههاى تحقيق حاضر نشان داد كه در اثر شش

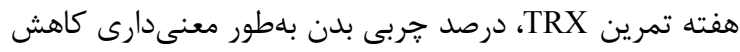

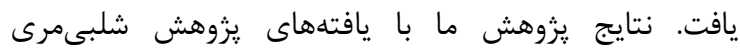

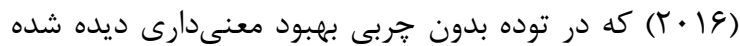
بود (و) همسو است؛ اما با نتايج يزوهش ملكوتىنيا و همكاران

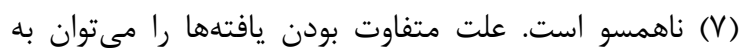
افراد شركتكننده در تحقيق نسبت داد، زيرا در تحقيق ملكوتىنيا و همكارانش از دختران لاغر غيرورزشكار استفاده شده بود كه داراى كموزنى نيز بودند و احتمالا هشت هفته تمرين نتوانست به ميزان كافى بر توده جربى و بدون جربى

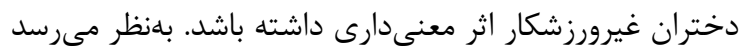
توسعه بافت عضله يس از تمرينات قدرتى باعث افزايش انرزى إنى

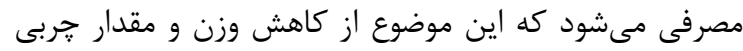
حمايت مى كند (ه). در تحقيق حاضر نيز، وزن مود و و

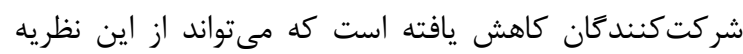
حمايت كند. از سوى ديخر، يافتههاى تحقيق حاضر نشان داد كه شش هفته تمرين TRX مىتواند قدرت و استقامت عضلات بالاتنه و ״ايينتنه را بهبود بخشد كه اين نتيجه، موافق نتيجه مطالعات

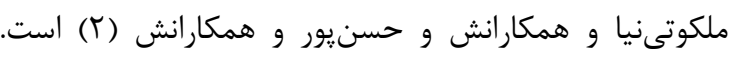
طبق تئورى سازگًارى عصبى، افزايش قدرت عضلانى در فاز

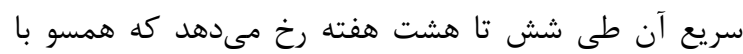

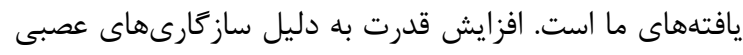
ناشى از فراخوان واحدهاى حركتى، تواتر برانخيخته شدن است واحدهاى حركتى و افزايش فعاليت اختيارى آكونيستها و و واستى

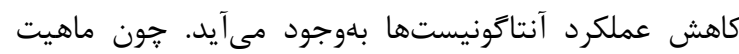

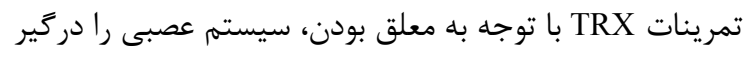

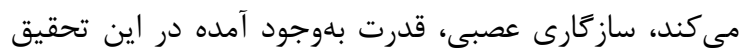

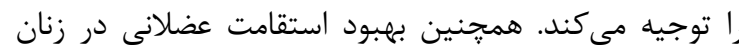

\section{REFERENCES}

1. McGill SM, Cannon J, Andersen JT. Analysis of pushing exercises: Muscle activity and spine load while contrasting techniques on stable surfaces with a labile suspension strap training system. J Strength Cond Res 2014; 28:105-116.

2. Hasanpour M. Comparison of the effect of two whole-body resistance training models on anaerobic, strength, body composition and functional factors in young and young Taekwondo athletes [MSc Thesis]. Tehran: North Tehran Branch, Islamic Azad University; 2017. [In Persian]

3. Ranjbar R, Hasanvand H, Habibi A, Goharpey Sh. Comparison of the Effect of TRX and Traditional Resistance Training on Some Factors of Body Composition and Balance in Sedentary Men. Jundishapur Scientific Medical Journal 2018; 16:621-630. [In Persian] 
4. Walker, K.S., Kambadur R, Sharma M, Smith HK. Resistance training alters plasma myostatin but not IGF-1 in healthy men. Med Sci Sports Exerc 2004; 36:787-793.

5. Bakhshaei, R., Faramarzi M, Bani- Talebi E, Kamran M. The Effect Of Eight Weeks Of TRX Instability Resistance Training With Handball Training On Plasma Levels Of IGF-I, IGFBP-3 in Adolescent Girl's Handball Players. Journal of Applied Exercise Physiology 2018; 14:223-236. [In Persian]

6. Kullman EK, Saylor SM, Little KD. Efficacy of whole-body suspension training on enhancing functional movement abilities following a supervised or home-based training program. J Sports Med Phys Fitness 2020; 60:244-50.

7. Arazi H, Malakoutinia F, Izadi M. Effects of eight weeks of TRX versus traditional resistance training on physical fitness factors and extremities perimeter of non-athlete underweight females. Phys Act Rev 2020; 6:73-80.

8. Gharakhanloo R, Saremi A, Omidfar K, Sharghi S, Gheraati MR. Effect of resistance training on serum levels of myostatin, GASP-1, IGF-I and IGFBP-3 in young men. Motor science and sport 2009; 13:67-79. [In Persian]

9. Filaire E, Lac G. Dehydroepiandrosterone (DHEA) rather than testosterone shows saliva androgen responses to exercise in elite female handball players. Int J Sports Medicine 2000; 21:17-20.

10. Aminilari Z, Daryanoosh F, Koshkie Jahromi M, Mohammadi M. The Effect of 12 Weeks Aerobic Exercise on the Apelin, omentin and Glucose in obese older Women with Diabetes Type 2. J Arak Uni Med Sci 2014; 17:1-10. [In Persian]

11. Cardinale M, Soiza RL, Leiper JB, Gibson A, Primrose W R. Hormonal responses to a single session of wholebody vibration exercise in older individuals. Br J Sports Med 2010; 44:284-288.

12. Tofighi A, Dehkordi AJ, Tartibian B, Fatholahi Shourabeh F, Sinaei M. Effects of Aerobic, Resistance, and Concurrent Training on Secretion of Growth Hormone and Insulin-Like Growth Factor-1 in Elderly Women. Journal of Isfahan Medical School 2012;30:427-438. [In Persian]

13. Kraemer WJ, Dunn-Lewis C, Comstock BA, Thomas G, Clark JE, Nindl BC. Growth hormone, exercise, and athletic performance: a continued evolution of complexity. Curr Sports Med Rep 2010; 9:242-252.

14. Berg U, Bang P. Exercise and circulating insulin-like growth factor I. Horm. Res Paediatr 2004; 62:50-58.

15. Copeland J, Heggie L. IGF $\square$ I and IGFBP-3 during Continuous and Interval ExerciseInt. J Sports Med 2008; 29:182187.

16. Nindl BC, Pierce JR. Insulin-like growth factor i as a biomarker of health, fitness, and training status. Med Sci Sports Exerc 2010; 42:39-49.

17. Abdi Keykanlo N, Rohani H, Asari F. Effects of 8 weeks aerobic training on body composition and plasma levels of insulin- like growth factor-1 and insulin-like growth factor binding protein-3 in obese women. Koomesh. 2014; 15:302309. [In Persian]

18. Dudgeon WD, Aartun JD, Thomas DD, Herrin J, Scheet TP. Effects of suspension training on the growth hormone axis. J Strength Cond Res 2011; 25:62.

19. Gregory SM, Spiering BA, Alemany JA, Tuckow AP, Rarick KR, Staab JS, et al. Exercise-induced insulin-like growth factor I system concentrations after training in women. Med Sci Sports Exerc 2013; 45:420-8.

20.Hasani-Ranjbar S, Soleymani Far E, Heshmat R. Rajabi H, Kohsari H. Time course responses of serum GH, insulin, IGF-1, IGFBP1, and IGFBP3 concentrations after heavy resistance exercise in trained and untrained men. Endocrine 2012; 41:144-151.

21. Sadeghi brojerdi S, Rahimi R. Response of GH and IGF-1 Hormones to Two Strong Resistance Programs with Different Rests Between Sets. SA J Res Sport 2009; 17:57-68.

22. Bird SP, Tarpenning KM, Marino FE. Liquid carbohydrate/essential amino acid ingestion during a short-term bout of resistance exercise suppresses myofibrillar protein degradation. Metabolism 2006; 55:570-577.

23. Field T, Hernandez-Reif M, Diego M, Schanberg S, Kuhn C. Cortisol decreases and serotonin and dopamine increase following massage therapy. Int J Neurosci 2005; 115:1397-413.

24. Steptoe A, Gibson EL, Vuononvirta R, Williams ED, Hamer M, Rycroft JA, et al. The effects of tea on psychophysiological stress responsivity and post-stress recovery: a randomized double-blind trial. Psychopharmacology 2007; 190: 81-89.

25. Arazi H, Malakoutinia F, Izadi M. Effects of eight weeks of TRX versus traditional resistance training on physical fitness factors and extremities perimeter of non-athlete underweight females. Phys Act Rev 2018; 6:73-80. 
26. Ghasemnian, A, E. Normohamadi, Azad A. Study The Changes of Insulin-Like Growth Factor -1 (IGF-I), Cortisol And Female Wheelchair Basketball Players Performance After 8 Weeks Upper Body Strength Training. Urmia Medical Journal 2017; 27:836-847. [In Persian]

27. Rezaei, N, Torkaman G, Movasseghe Sh, Hedayati M, Bayat N. The Comparison of 6-Week Resistance Training And Pulsed Electromagnetic Field on Talp, Ca, P, Cortisol, And Anthropometric Parameters In osteoporotic Postmenopausal Women. Iran J Endocrin Metabolism (IJEM) 2012; 14:380-391. [In Persian]

28. Surati Jablu, D, Attarzadeh Hosseini R. Effects of Resistance and Endurance Exercises on Serum Androgens, Cortisol and Lactate in Menopause Women. Iran J Health Physic Act 2012; 3:1. [In Persian]

29. Dashti H, Galedari M, Siahkuhian M. Acute Testosterone and Cortisol Hormonal Responses to Volume and Strength Resistance Traiining in Untrained Young Males. Iran Periodic J cong Sys 2015; 6:55-64. [In Persian]

30. Borg G, Editor. Borg's perceived exertion and pain scales. Stockholm: Human Kinetic; 1998.

31. Borg GA. Psychophysical bases of perceived exertion. Med sci sports exerc 1982; 14:377-381.

32. Borujeni H, Nazarali P, Naghibi S. Effect of Four Weeks HIT on the Levels of GH, IGFBP-3, IGF-1 and Serum Cortisol and some Performance Indicators in Iran Women National Basketball Team. J Sport Biosciences 2013; 5:3548. [In Persian]

33. Nishida Y, Matsubara T, Tobina T, Shindo M, Tokuyama K, Tanak K, et al. Effect of low-intensity aerobic exercise on insulin-like growth factor-I and insulin-like growth factor-binding proteins in healthy men. Int J Endocrinol 2010; 2010:452820.

34. Prokopy MP, Ingersoll CD, Nordenschild E, Katch FI. Closed-kinetic chain upper-body training improves throwing performance of NCAA division I softball players. J Strength Cond Res 2008;22:1790-98.

35. Puche JE, Castilla-Cortazar I. Human conditions of insulin-like growth factor-I (IGF-I) deficiency. J Transl Med $2012 ; 10: 224$. 